\title{
Effectiveness of Planed Teaching Programme on Episiotomy care
}

\author{
Poonam Gadiya ${ }^{1}$,Sijo koshy ${ }^{2}$, Ravindra H. $\mathrm{N}^{3}$. \\ ${ }^{I}$ Student, Sumandeep nursing college, Sumandeep vidyapeet,Piparia, Vadodara-391760, Gujarat, India, \\ ${ }^{2}$ Associate Professor, Department Of Obstetrics and gynecological Nursing, Sumandeep Nursing College, \\ Sumandeep Vidyapeeth, Piparia, Vadodara-391760, Gujarat, India. \\ ${ }^{3}$ Principal, Sumandeep Nursing College, Sumandeep Vidyapeeth, Piparia, Vadodara-391760, Gujarat, India,
}

\begin{abstract}
:
Background: Perineotomy, or episio to myi sasurgically plan edincisionon the perineumand the posteriorvaginalwallduringsecondstageoflabor.The incision, which can be idlineoratanangle from the posteri or end of the vulva, is performed under local anesthetic (pudendaanesthesia), and issutured closed after delivery. It is one of the mostcommonmedicalproceduresperformedonwomen, andalthoughitsroutineuse in childbirth. Care of the episiotomy wound is required to protect from infection or post complication now a days the rate of episiotomy is increasing because of awareness and skilled worker for protect perineal laceration .
\end{abstract}

Aims and objective: The aim of this study to evaluatetheexistingknowledge regardingepisiotomycare. To prepare and introduceplanned teachingprogrammer regarding episiotomycare. To evaluatethe differences between pretest and post test score. To determine the association between the posttest knowledge score and selected demographic variables.

Material and Methods: A one group pre-test post-test pre-experimental design and evaluative approach was adopted. The study was conducted among 60 prmi para women conveniently selected hospitals of Vadodara. The content validity of the tool and teaching plan was established. The reliability of tool was established by testing the internal consistency by using Test -retest method.

Results: Result of study indicate that p-value $=0.000<0.01$, the difference between the Pre-test and Post-test scores is highly significant at $1 \%$ level of significance this shows that the planed Teaching Programme on episiotomy care is effective.

Conclusion: This study concluded that planed teaching program is effective tool to improve knowledge of primi para mother regarding episiotomy care.

Keywords: Assess, Effectiveness, planed Teaching Programme,episiotomy, hospiral,perineal laceration.

\section{Introduction}

An episiotomy is a surgical incision of the perineum made to prevent tearing of the perineum with births and to release pressure on the fetal head with birth. An episiotomy incision is made with blunt tipped scissors in the midline of the perineum (a midline episiotomy) or begun in the midline but directed lateral away from the rectum (a mediolateral episiotomy).

A doctor may decide to perform an episiotomy for a variety of reasons. These include a perception that the fetus is distressed after entering the birth canal, the baby's head is perceived to be too large, the baby is breach, its shoulders get caught, or if the process of delivery proceeds Rigid perinem ,Anticipating perineal tear ,Operative delivery ,Previous perineal surgery so quickly that the doctor believes the vagina will be overstressed.

Today, when the cost of medical treatment and care is soaring, economical care of patients with episiotomy can be provided if nurse and midwives realize the relevance of their case and potential impact of the advocated procedure in wound healing. The best way to provide cost effective care is to empower the clients to bring about change in behavior.to change of behavior of a patient by the teaching or guiding so PTP is the best option to educate regarding episiotomy care.

\section{Statement of problem:}

"Astudytoassesstheeffectivenessofplannedteachingprogram(PTP)on

knowledgeregardingepisiotomycareamongprimiparamothersinpostnatalwardin selected hospital ofVadodara"

Objectives of the study:

- To evaluatetheexistingknowledge regardingepisiotomycare.

- Toprepareandintroduceplannedteachingprogrammeregarding episiotomycare.

- To evaluatethedifferences between pretest and post test score.

- To determinetheassociation betweentheposttestknowledgescoreand selected demographicvariables. 


\section{Hypothesis}

$\mathrm{H} 1$ :ThemeanposttestscoresofsubjectsexposedtoPTPwillbegreaterthan theirmeanpretestscoresasmeasuredbyplannedknowledgequestionnaireat 0.05 level ofsignificance.

$\mathrm{H} 2$ :Thereisasignificantassociationbetweenposttestknowledgescores selected socio-demographicvariables.

\section{Materials And Methods}

Research Approach: Evaluative research approach was used.

Research Design: A one group pre-test post-test Pre experimental research design was adopted

Setting of the Study: The study was conducted in selected hospitals of Vadodara.

Target Population: The target population for this study consisted of primi para mother.

Sample: The sample for the present study comprises of 60 primi para mother selected hospitals of Vadodara.

Sampling technique: Non-probability convenience sampling technique was used to select the sample for this study.

\section{Development of tool for data collection:}

Section A: DemographicVariables,age,cast,educationalstatus,media for information,occupation,type of family,residence.

Section B: Structured questioner schedule on episiotomy basic knowledge about episiotomy,Diet,Exercise,Care,Preventivemeasure it consist of 25 question.

Validity of instrument:The Self Reportive Structured Interview tool and planned Teaching Programme were given to 11 experts along with the blue print and objectives of the study to establish the content validity of the tool and PTP regarding episiotomy care The experts were from the field of Nursing and Medical, Research department. They were requested to give their opinion and suggestions regarding the relevancy of the items in the tool.

Reliability: After obtaining formal administrative permission the Gujarat,Hindi and English version of the tool was administered to 6 samples selected as per the set criteria. The scores were calculated and then given for statistical analysis. The reliability was established by using test re-test method.

Data collection procedure: Prior final study a formal permission is obtained on 25.10.2013 from the medical superintendent of Dhiraj hospital,Redham maternity hospital and Rushikesh Hospital Vadodara. Data was collected from 7-11-2013to30-11-2013.After identifying the samples objectives of the study were discussed and consent for the participation in the study was taken from the selected group. The investigator assured the subjects about the confidentiality of the data. The investigator herself administered the questionnaire for the pretest.

\section{Analysis of data}

Both descriptive and inferential statistics analyzed on the basis of the objectives and hypotheses of the study. The knowledge of primi paramother regarding episiotomy care assessed before and after the administration of PTP would be calculated using mean, median, range and standard deviation.

The significance of difference between the mean pre-test and post-test knowledge score of primipara mother would be calculated using paired' $t$ ' test. The association between demographic variables and post-test knowledge score regarding prevention and control of tuberculosis would be determined by ANOVA. Data presented in the form of tables and graphs.

\section{Results}

The analysis is made on the basis of objectives and hypothesis. The data analysis is planned to include descriptive and inferential statistics. Data is analysis in following parts:

Part-I:-Analysis of demographic data of samples

Part-II:-Analysis regarding effectiveness of PTP

Part-III:-Analysis regarding association between pre-test knowledge score and demographic variables

Part-IV:-Analysis of various aspects of PTP

\section{Section I: - Analysis Of Demographic Data Of Samples}

- Findingswereindicatesthat 76.7\%respondentswereHinduand $1.7 \%$ wereChristian and $18.3 \%$ wereMuslims and remainingare $3.3 \%$.

- Findings were indicates that $0 \%$ respondents were uneducated and $73.3 \%$ were having primaryeducationand $25.0 \%$ werehavingsecondaryeducationandremaining $1.7 \%$ are graduate.

- Findingswereindicatesthat $35 \%$ respondentsbelongtonuclearfamily and $65 \%$ were belongs to joint family. 
- Findingswereindicatesthat $20 \%$ respondentswerehousewifeand13.6\%wereselfemployeeand $38.3 \%$ wereprivate-employeeandremainingisgovernmentemployee $5.0 \%$

- Resultindicatesthat $30 \%$ respondentswerebelongingtoruralareaand $18.3 \%$ were belongingtourbanareaand $38.3 \%$ werebelongingtosemi-urbanareaand5.0from slam area.

- Findingwereindicatesthat $16.7 \%$ ofrespondentsgotinformationfrommassmedia and36.7\% respondentsgotinformationfromfamily/relativesandfriends $23.3 \%$ aer gotinformationfrommedicalprofessionaland $23.3 \%$ aregotinformationfrom printed material likenewspaper.

\section{Section I: -Analysis Regarding Effectiveness Of PTP}

Since $\mathrm{p}$-value $=0.000<0.01$, the difference between the Pre-test and Post-test scores is highly significant at $1 \%$ level of significance this shows that the planed Teaching Programme on episiotomy care is effective.

\begin{tabular}{|l|l|l|l|l|l|l|}
\hline Overall & Maximum & Mean & $\begin{array}{l}\text { Standard } \\
\text { Deviation }\end{array}$ & $\begin{array}{l}\text { Mean } \\
\text { Percentage }\end{array}$ & t-value & p-value \\
\hline Pre Test & 25 & 5.77 & 2.126 & 21.74 & 40.361 & 0.000 \\
\hline Post Test & 25 & 20.95 & 1.93474 & 83 & & S.p $<0.05$ \\
\hline
\end{tabular}

Table -Significant differencein thepretest and posttest knowledgescore

This table shows statistically that there is significant difference in the pre test and post test knowledge score regarding episiotomy care among primi para mother this statistically provesthe effectiveness of the PTP in all area of episiotomy care. Thus means $\mathrm{H}_{0}$ is Rejected. And there is $28 \%$ association between pretest and post test

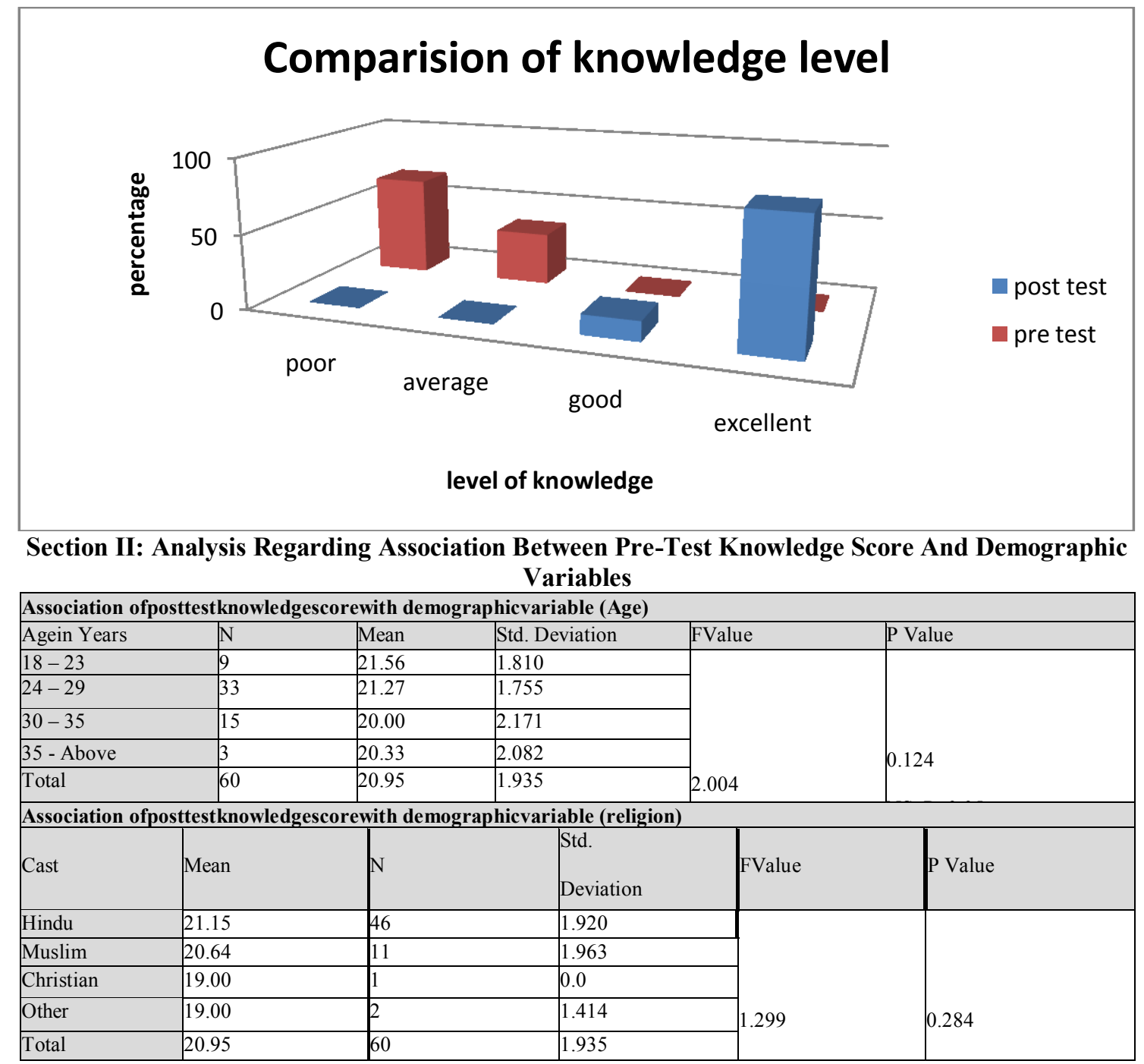




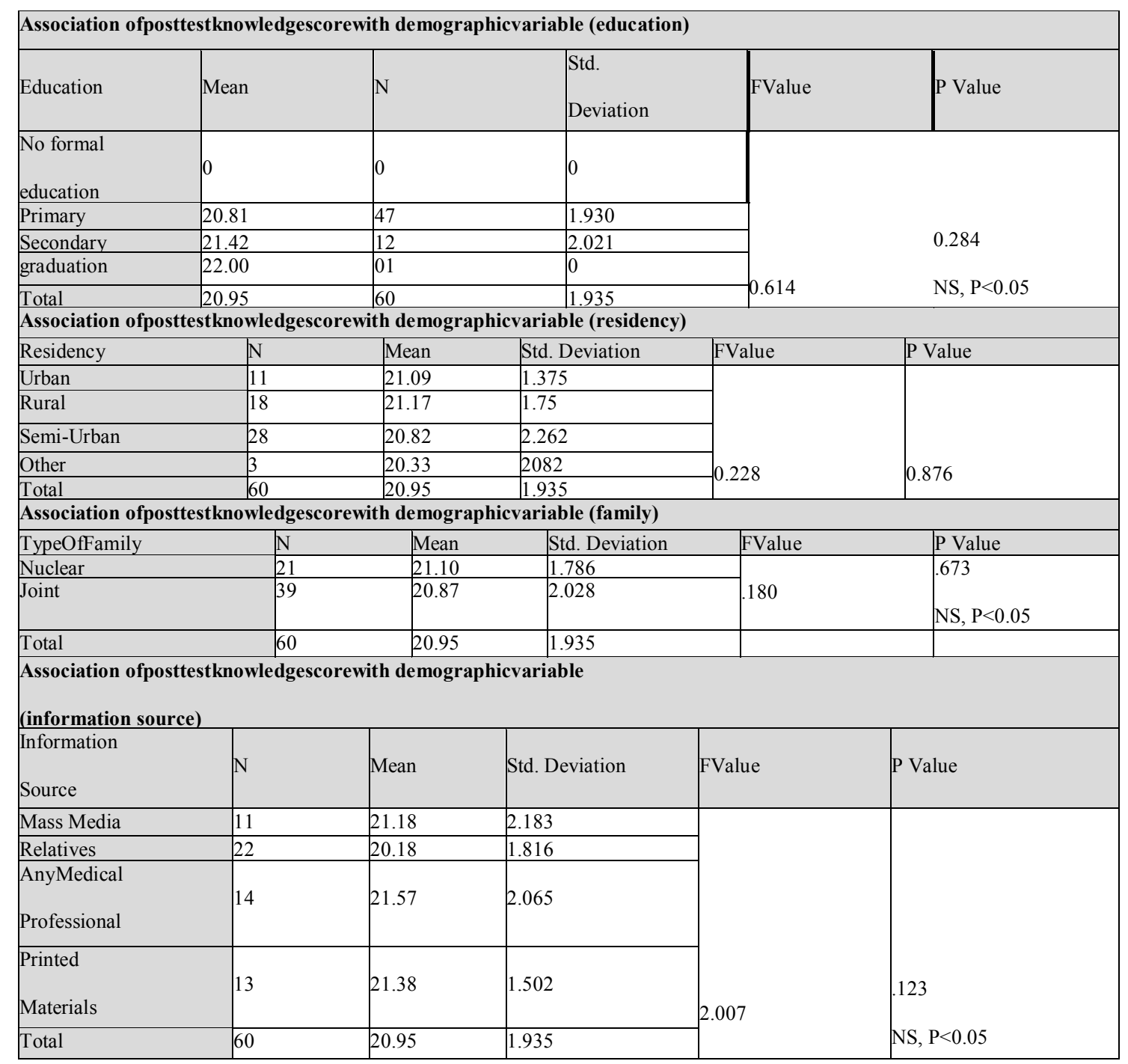

Thepresentstudyrevealedthatthereisanotsignificantassociationbetween pretestknowledgescoreandage $(\mathrm{p}<0.05, \mathrm{f}=2.004)$, religion $(\mathrm{p}<0.05, \mathrm{f}=.284)$, typesoffamily $(\mathrm{p}<0.05, \mathrm{f}=.673)$, education $(\mathrm{p}<0.05, \mathrm{f}=.284)$ sourcesof information $(\mathrm{p}<0.05, \mathrm{f}=2.007)$, occupation, $(\mathrm{p}<0.05, \mathrm{f}=.853)$ residence $(\mathrm{p}<0.05, \mathrm{f}=.228)$.

Section III: assessment of knowledge score regarding episiotomy care A. assessment of pre test level of knowledge scores

\begin{tabular}{|l|l|l|l|}
\hline Level Of Knowledge & Score Range & Percentage Range & Pretest \\
\hline Poor & $0-6$ & $0-25$ & 66.5 \\
\hline Average & $7-12$ & $26-50$ & 35.0 \\
\hline Good & $13-19$ & $51-75$ & 0 \\
\hline Excellent & $19-25$ & $76-100$ & 0 \\
\hline
\end{tabular}




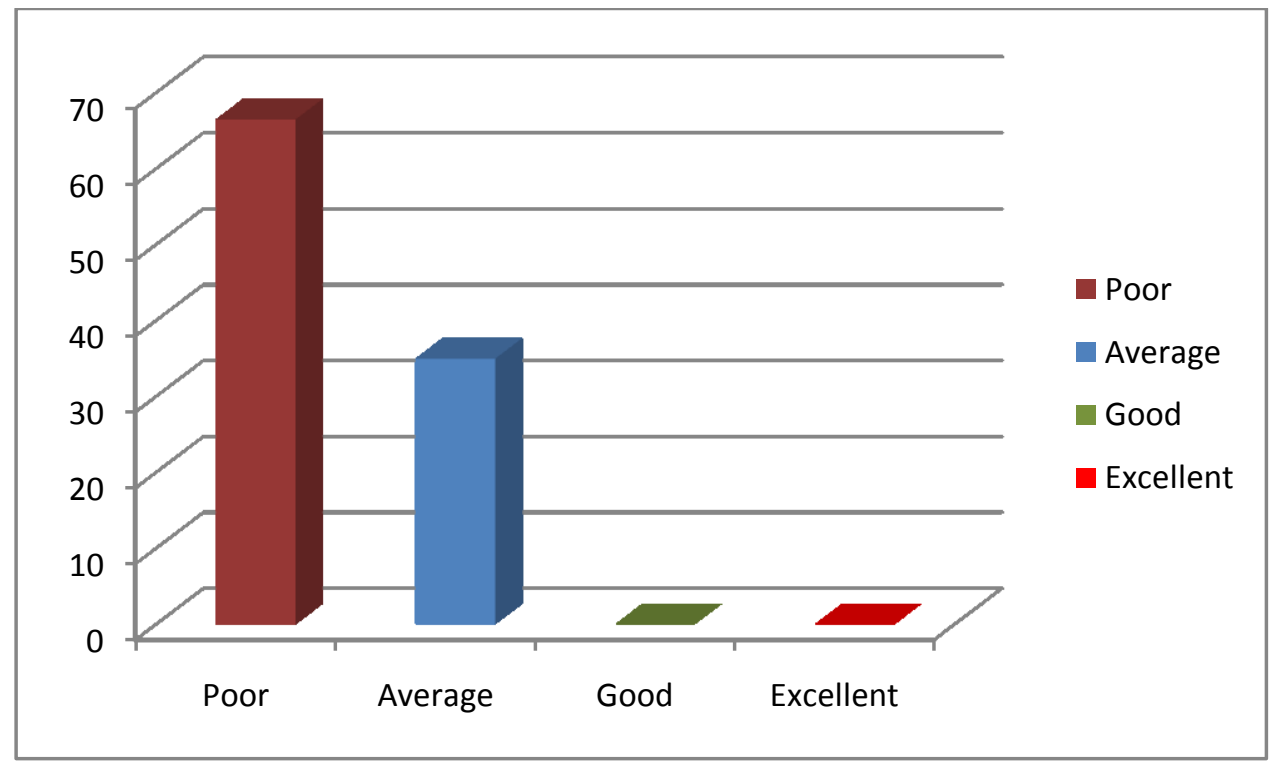

Percentage wise distribution of pre test knowledge level

B. Post test knowledge score of subjects on episiotomy care.

\begin{tabular}{|l|l|l|l|}
\hline Level Of Knowledge & Score Range & Percentage Range & Pretest \\
\hline Poor & $0-6-$ & $0-25$ & 0 \\
\hline Average & $7-12$ & $26-50$ & 0 \\
\hline Good & $13-19$ & $51-75$ & 13 \\
\hline Excellent & $19-25$ & $76-100$ & 85 \\
\hline
\end{tabular}

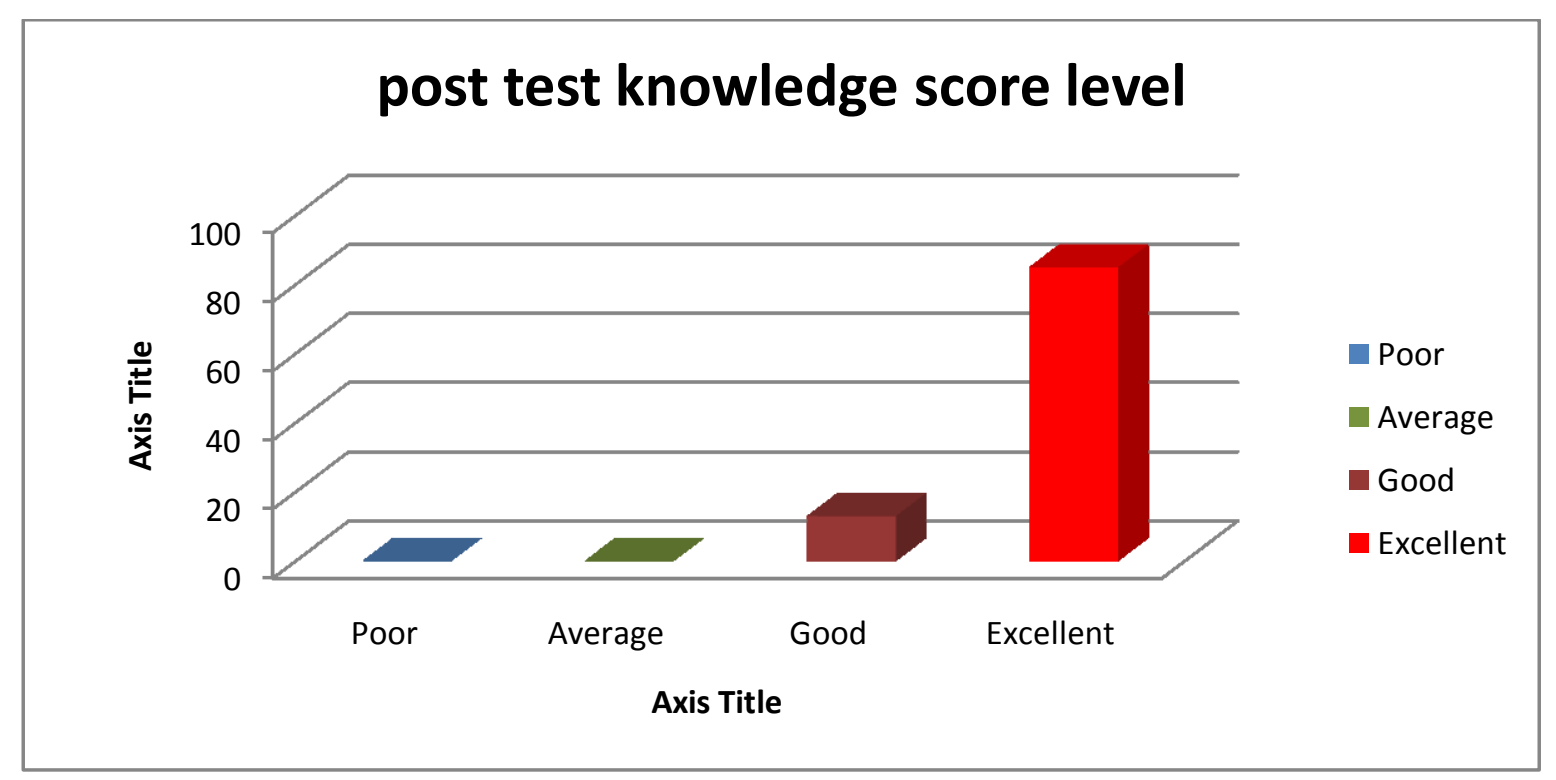

Level of knowledge in the post test

\section{Conclusion}

The findings of this study have been discussed with reference to the objectives and hypothesis. The pre testing of primi para mother knowledge regarding episiotomy care show that nurses have less knowledge about episiotomy care. This indicates the need for imparting necessary education and information regarding episiotomy care.

\section{Acknowledgement}

I express my gratitude and thanks towards all who have directly or indirectly helped me to complete this study and their support in each major step of the study. 


\section{Limitations of the Study}

The following points were beyond the control of the investigator.

1. The study is limited to small sample size

2. The assessment of effect of the PTP is limited to one post-test conducted on the 7th day.

\section{Recommendation:}

- Thiseducationshouldbegivenatthetimeofantenatalperiodsomothercan belearningmore and takinginterest. Becauseofsheis physicallyableto cooperate.

- Thehealthprofessionalcouldarrangeweeklyeducationalprogrammeforpre and postnatal mother.

- Publiclibrariesintheschoolandcollegeshouldhaveresourcesmaterialson episiotomy.

- Nursesshouldupdatetheirknowledgeconstantlyandhelpmotherforearly healing.

- Collegeteachers,parents,leadersandhealthprofessionalshouldbeoriented and sensitized to thetopic.

\section{Ethical Standards}

This study was conducted after getting approval from the Institutional Ethics Committee and after obtaining written consents from all subjects.

Source of funding: The authors did not receive any financial support from any third party related to the submitted work.

Conflict of interest: The authors had no relationship/condition/circumstances that present a potential conflict of interest.

\section{References}

[1]. DuttaAnupama.;Effectivenessofmoistanddryheatapplicationonhealingof episiotomywound in postnatal mothers; Dissertation 2008 .

[2]. Iffy,Charles, Operativeperinatologyinvasiveobstetrictechniques;1983;Page 730.

[3]. AdelePillitteri;MaternalandChildhealthNursing;Careofthechild bearingand child drearingfamily; 4 th edition; page512-514; 2003

[4]. ParkK.,'PreventiveandSocialMedicines'18 ${ }^{\text {th }}$ ed.PremNagarBhanotJabalpur

[5]. 2005, pg. 20

[6]. Globalstudiesconfirmmultiplemother-childbenefitsfromEPI-Nochildbirth system training.www.episiotomycare.com.

[7]. FernandoAlthabe,JoseM.Belizan,EduardoBergel;Episiotomyratesin primiparouswomeninLatinAmerica:hospitalbaseddescriptivestudy:British MaternityJournal; 2008.Pg. no-56-58

[8]. AmericanCollegeofObstetriciansandGynecologists.ACOGpracticebulletin:

Clinicalmanagementguidelinesforobstetriciangynecologists.No.71,April2007. ObstetGynecol2006; 107(4):957-962. 